\title{
HAZARDOUS WASTE MANAGEMENT IN COSTA RICA: AN ACADEMIC-SMALL COMPANY COLLABORATION
}

\author{
LUIS G. ROMERO-ESQUIVEL \& ANDREA ACUÑA-PIEDRA \\ Environmental Protection Research Center (CIPA), School of Chemistry, \\ Instituto Tecnológico de Costa Rica (ITCR), Costa Rica
}

\begin{abstract}
Hazardous waste treatment options in developing countries are limited. The main problems include scarce or no specialized facilities, and a lack of analytical tools for characterization. In some cases, there are also minimal regulations. Costa Rican hazardous waste legislation dating from the 1990s was improved over the last decade. We describe the management system implemented in Costa Rica that permits an increase in the amount of hazardous waste that could be properly managed, from around 7,432 tons in 2015 to 31,268 tons $(76 \%)$ in 2019 . Similarly, during the same period, the number of official waste-generator companies and specialized waste management companies increased from 107 to $736(85 \%)$, and from 11 to $35(69 \%)$, respectively. We also present the collaboration of a public university with a local small company. Characterization of hazardous waste and evaluation of possible treatment methods were performed at a laboratory level in the university. Later, the small company, under university staff supervision, scaled up the selected treatment method. This small company has two reactors with capacities for 2,000 and $500 \mathrm{~kg}$, both are equipped with $\mathrm{pH}$ and oxidation potential reduction sensors that control the pumps used for adding acid, base or oxidants into each reactor. Examples of successfully treated liquid waste are sulfide and cyanide wastes from a metal finishing company. Both types of wastes were oxidized using chlorine, to obtain calcium sulfate and nitrogen gas, respectively. Heavy metal waste is precipitated and then solidified using Portland cement. Hazardous organic waste is normally sent to a local cement kiln for co-processing; however, some waste does need pre-treatment before burning, such as the case of di-isocyanates, which, during burning, could generate hydrogen cyanide. So the waste has to be transformed into urethanes by an aqueous reaction, with ethanol and ammonia. This study demonstrates cooperation between academia, through technical knowledge and analytical skills, and industry, providing appropriate infrastructure and management in accordance with local regulation.
\end{abstract}

Keywords: Costa Rica, developing countries, environmental legislation, hazardous waste, hazardous waste treatment, university-industry cooperation, waste disposal methods.

\section{INTRODUCTION}

The use of chemicals in industry, commerce and global research is becoming more common. The chemical industry is expected to continue to grow steadily until 2030 [1]. The mishandling of chemicals, as well as their residues, can adversely affect human health and the environment. The World Health Organization (WHO) estimates that at least 355,000 people die from accidental poisoning each year, with two-thirds of those deaths occurring in developing countries. Poisoning is closely related to excessive exposure to toxic chemicals, including pesticides, and the inappropriate use of these products [1].

As part of the use of chemicals, there is an intrinsic generation of hazardous waste. In response to the identification of global problems regarding treatment and management of hazardous waste at the international level, the "Basel Convention on the Control of Transboundary Movements of Hazardous Wastes and their Disposal" was adopted. This agreement establishes, among other measures, the possible treatments that can be offered to process hazardous waste, for either its recovery or the reduction of risk. As a signatory to this agreement since 1994, Costa Rica subscribes to the treatment options that are allowed for hazardous waste mentioned in that convention [2]; however, only those that may lead to 
recycling, recovery, regeneration and reuse have been considered appropriate, among which are [3]:

- Use as fuel (other than direct incineration) and power generation.

- Recovery or regeneration of solvents.

- Recycling or recovery of organic substances (that are not used as solvents); and metals, metallic compounds and other inorganic materials.

- Regeneration of acids, bases and used oils.

- Recovery of components from catalysts and/or components used to reduce contamination.

- Soil treatments that benefit ecological agriculture or other improvement.

As part of the fulfillment of this agreement, as well as the interest of Costa Rica in preserving its environment and the health of its inhabitants, legislation was created surrounding the integrated management of waste, with the proper management of hazardous waste being accorded great importance; however, compliance with that legislation can be complex, especially for small businesses that work as waste managers. Technologies and methods developed to treat and/or recover energy from waste are often complex; in addition to limitations on, or unavailability of, the necessary resources and knowledge. These small companies has seen a need to seek support from the academy, which, through their experience and knowledge, could provide the necessary tools.

This article describes the Costa Rican legislation and procedures that must be followed in order to responsibly manage hazardous chemical waste. In addition, we present the specific case of successful synergy between a small waste management company, Greco Chemical; and the public university, Costa Rica Institute of Technology (ITCR).

\section{HAZARDOUS WASTE MANAGEMENT IN COSTA RICA}

\subsection{Legal context}

In Costa Rica, the Ministry of Health has the responsibility for acting as the lead institution in integrated waste management. This institution is responsible, among other things, for issuing regulations and ensuring compliance; defining indicators in this area; encouraging inter-institutional public environmental action; and encouraging the development of new technologies, models and investments to improve waste management [4]. This ministry is also supported by the Ministry of Environment and Energy (MINAE), in actions related to the management of hazardous waste, such as the creation of regulations and tools, verification of compliance, updating, definition of goals and indicators, development of diagnoses on the national situation regarding hazardous waste, carrying out environmental impact assessments and fulfilling the functions of the Environmental Comptroller, for companies that manage hazardous waste [2]. MINAE helps to promote socially fair and environmentally appropriate commercialization structures for recoverable waste and the products obtained from this, as well as for requesting life cycle analyses or similar studies to evaluate risks and impact [4].

The implementation of regulations dates back to 1998, when three regulations, remaining in force to date, were decreed. Initially, Regulation 27000-MINAE, "Regulation on the characteristics and list of industrial hazardous waste" was created. This regulation establishes the characteristics that allow waste to be classified as hazardous. Within these, are mentioned the limiting parameters for infectiousness, toxicity, flammability, explosiveness, corrosion and reactivity [5]. Also decreed, Regulation number 27001-MINAE, "Regulation for the 
management of industrial hazardous waste" [6]. It establishes eight stages and guidelines to be met by hazardous waste generators and managers at each step. The stages are: generation, accumulation, pretreatment, storage, transportation (outside the generator facilities), treatment, energy recovery and final disposal [6]. It is understood that some waste does not go through all the stages; as, for example, conditioning within the generator facilities is not always possible or necessary. Moreover, not all waste can be assessed, some are only treated and sent for final disposal with a lowered degree of risk. Regulation 27002-MINAE was created: "Regulation on the procedure to carry out the extraction examination to determine characteristics that make a waste hazardous due to its toxicity to the environment" [7], with the objective to determine whether a residue has hazardous characteristics, using a leaching procedure similar to the US Environmental Protection Agency (USEPA) toxicity characteristics leaching procedure (TCLP) [8]. Finally, there is regulation 24715-MOPTMEIC-S, "Regulation for the land transport of dangerous products", rules on the transport of hazardous materials (not only waste) [9].

In 2010, the country's first "Law for Waste Management" (Law 8839) was created in Costa Rica. In 2012, the regulations of this law (37567-S-MINAE-H): "General regulation of the law for waste management" came into force. Both documents focus not only on hazardous waste, but also on ordinary waste as well as waste classified as "Special". Among the topics included in this law and its regulations, is the need for the companies responsible for waste handling, at any stage, to ensure compliance with proper management and traceability. The responsibilities of the waste generators and managers are identified, as well as those of the government entities related to compliance, with regulations on this matter. The sanctions that must be imposed for poor waste management are stipulated, in addition to all the requirements and restrictions related to transboundary movements. For example, in the specific case of hazardous waste, transportation without authorization, leaving hazardous waste in unauthorized places and the mixing of hazardous waste with non-hazardous waste are penalized in a "very serious" manner [4]. Carrying out any of these activities may be punished with a fine of approximately $(\$ 16,000-\$ 79,000)$, in addition to the repair of any environmental damage.

From 2010, when the Law for Waste Management was created, a series of modifications was made to the legislation, regarding the management of hazardous waste, especially because Costa Rica made the decision to become part of the Organization for Economic Cooperation and Development (OECD). Thus, waste classified as hazardous was redefined according to the list in the "Basel Convention on the Control of Transboundary Movements of Hazardous Wastes and their Disposal": the waste became subject to control by the OECD, in Decision C (2001)107. The responsibilities of waste generators and managers in all stages of waste management are specified in greater detail. Therefore, modifications were made to the legislation, and regulation number 41052-S: "Regulation of recoverable waste recovery centers" was introduced in June 2018 [10]. Here, compliance regarding physical space, good practices and documentation showing that waste managers have carried out storage, treatment, recovery or final disposal of waste (including those of a hazardous type) are indicated. Additionally, in January 2019, regulation 41527-S-MINAE: "General regulation for the classification and management of hazardous waste" came into force [2]. This last regulation expands the necessary requirements for the integrated management of hazardous waste in Costa Rica. 


\subsection{Requirements for the management of hazardous waste in Costa Rica} (generators and waste managers)

Considering all the existing regulations before the Law 8839 of 2010, as well as the regulations that arose after this, both waste generators and waste managers are forced to comply with a large number of requirements [11], such as:

- Carry out integrated management of the waste generated (at all stages, from generation to final disposal).

- Implement an Integrated Waste Management Program. This is a document that contains the diagnosis of the current situation regarding the waste management of a generator or a waste manager, in addition to proposing improvements. This document must have a section dedicated exclusively to the integrated management of hazardous waste. The document details each hazardous waste that is generated or managed, including its destination, risk of handling, as well as ways to prevent and reduce its generation and to minimize risk.

- Register with the Ministry of Health any movements and release of hazardous waste.

- Notify the MINAE Environmental Comptroller of the dispatch of waste outside generator facilities.

- Have the necessary permits for the transboundary movement of hazardous waste.

- Guarantee that the packing and labeling of hazardous waste is carried out in accordance with the aforementioned regulations.

- Have adequate storage, recovery, transportation, treatment or final disposal facilities, as dictated by regulations.

- Immediately inform the Ministry of Health in the case of any disappearance, loss or spillage of hazardous waste.

- Prepare and implement an Occupational Health Plan and an Emergency Care Plan.

Meanwhile, in the accumulation stage, it is requested that separation points be placed as close as strategically possible to the waste generation focus. Chemical incompatibilities must be respected; and there must be appropriate containers, labeled according to the type of waste to be accumulated.

For the storage stage, the same requirements for safety and labeling of containers, and respect for incompatibilities during accumulation, must be followed. Also, waste must be taken outside the generator facilities for assessment, treatment or final disposal at least once a year, for each type of waste contained, or whenever storage reaches 1,000 L. Care must be taken in storage, with pallets also according to the type of waste.

Regarding transportation, the waste manager and the generator who contracts transport must comply with the rules stated for transporting hazardous materials. Only trained drivers and authorized transportation vehicles can perform this task. They must respect chemical incompatibilities, with pallets and safe packaging. They must carry documentation indicating the waste(s) being transported, with notification of that movement made to MINAE and with national circulation permits.

Included among the requirements that waste managers must abide by for waste treatment are environmental impact studies, risk analyses, and use of treatment methods that lead to the recovery of the waste or at least to reduce its dangerousness, in the event that it cannot be recovered. 
The final disposal allowed in Costa Rica is the export or shipment to sanitary landfills, as long as it is waste that has been treated or placed in safety cells in the sanitary landfill, cells that prevent the waste from causing damage.

It is very important to mention that Costa Rica's regulations maintain the concept of "survival of responsibility", which is defined as: "The entire responsibility of the generator remains until the hazardous waste is assessed or disposed of permanently. The waste manager hired by the generator will be jointly responsible for it, once the waste has been received for its integrated management" [2].

\subsubsection{Notifications of waste movements}

As mentioned, waste must be take outside of the generator facilities at least once a year (6 months, in the case of the waste managers), or when there is a stored quantity of 1,000 L. Often, both due to space availability and risk issues in storage, waste must be removed much more frequently, making the transportation of waste a daily practice throughout the national territory.

Each of these movements must be notified to the MINAE Environmental Comptroller. In order to carry out the notifications effectively, the System of Integral Management of Hazardous Waste (SIGREP) has been created by this ministry. This is a web platform that allows generators to register all of the hazardous waste they generate; also, waste managers can register the hazardous waste that they can accept and for which they can provide transportation, storage, treatment, recovery or final disposal. In addition, this platform enables the registration of drivers and vehicles that have the corresponding training and permits to carry out the transportation work. Prior to each movement of waste outside the facilities of the generator or the waste manager, MINAE is notified of the waste being transported, its physical and chemical characteristics, incompatibilities, quantity, destination, the driver's name and vehicle in which it is transported. Fig. 1 graphically presents the general process of hazardous waste management in the country.

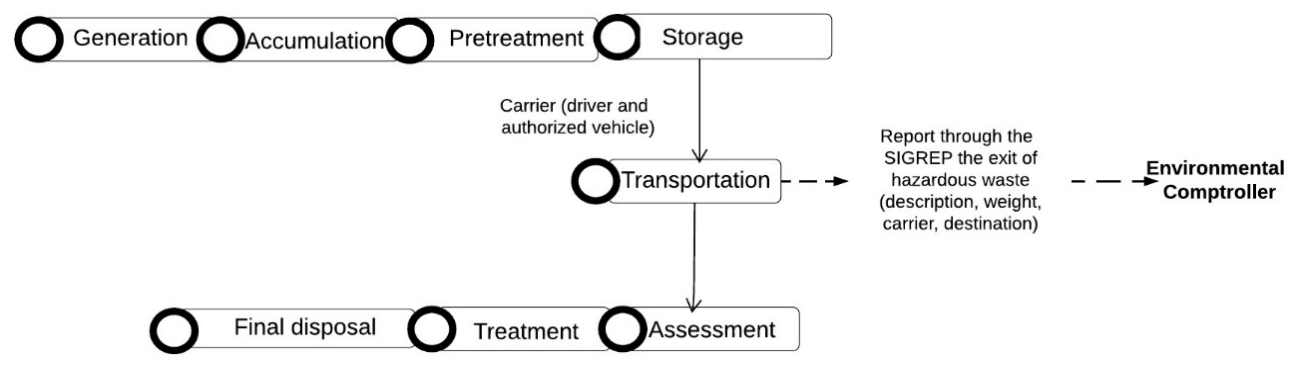

Figure 1: General process of hazardous waste management in Costa Rica.

\section{APPLICABILITY OF INTEGRATED HAZARDOUS WASTE MANAGEMENT IN PRACTICE}

Although the legislation is exhaustive, it is not always possible to apply it as the regulations suggest. Currently, many waste managers work illegally, and many waste generators do not meet the minimum requirements established; however, the SIGREP platform has provided data that supports the improvements made and also provides evidence for decision-making.

Subsequently, we present the results reported on the platform, followed by details regarding an authorized manager. 


\subsection{Hazardous waste management from 2015 to 2019}

For the year 2019 [11], the Costa Rica Environmental Comptroller reports on the management of 31,268 tons of hazardous waste, transported from the generation point to the different waste managers. The processes these residues were subjected to were: use as an alternative fuel, solvent recovery, recovery of organic substances, neutralization, oil regeneration, and recovery of lead.

The waste managed in the largest quantity was lubricating oils (9,218 tons); followed by solids contaminated with harmful impurities (4,400 tons); and then third, paint, solvent and sludge residues produced by painting, coating and cleaning activities $(4,300$ tons). Other waste managed in lesser quantities were: contaminated fuels, plastic waste, contaminated absorbent materials and textiles, lead acid batteries, solvents, and other oils.

Since the introduction of this platform, there has been an increase in the amount of waste processed and the number of generating companies, managers, transporters and transport manifests reported (Table 1) [11]. This indicates the impact that the new legislation has had on the entire waste chain, from generation to final disposal.

Table 1: Hazardous waste generation and management in Costa Rica from 2015 to 2019.

\begin{tabular}{|l|c|c|c|}
\hline Topic & 2015 & 2019 & Increase (\%) \\
\hline Total hazardous waste (ton) & 7,439 & 31,268 & 76.2 \\
\hline Generating companies & 107 & 736 & 85.5 \\
\hline Management companies & 11 & 35 & 68.6 \\
\hline Transport companies & 23 & 32 & 28.1 \\
\hline Total transportation manifests & 1,192 & 12,138 & 90.2 \\
\hline
\end{tabular}

\subsection{Example of a small hazardous-waste management company}

Greco Chemical is a small Costa Rican company with which the Research Center for the Protection of the Environment (CIPA) of the ITCR has had a successful relationship regarding the research and development of efficient methods for treating hazardous chemical waste, since 2012. Tests were initially carried out in the ITCR laboratories, to design an appropriate treatment method for a series of hazardous wastes (detailed in next section). Once these methods were validated, they were able to be scaled up in the Greco Chemical facility.

Currently, the company has a $200 \mathrm{~m}^{2}$ treatment and storage facility and a small laboratory to characterize the waste and to test treatment methods. The plant has the capacity to treat waste in small quantities ( $25 \mathrm{~mL}$ vials), up to $20,000 \mathrm{~kg}$. It has two reactors with capacities of $2,000 \mathrm{~kg}$ and $500 \mathrm{~kg}$, with $\mathrm{pH}$ and oxidation potential reduction (ORP) controllers for dosage of chemical products.

As a waste manager, the company has authorization from the Ministry of Health and is registered on the SIGREP platform, which, as previously mentioned, allows for the notification of waste movements from generators to management companies.

Currently, the company offers hazardous waste treatment services by both physical and chemical methods (Table 2, Fig. 2). In the case of physical treatments, it offers filtration, gravity separation, evaporation, carbon absorption, ion exchange and solidification (immobilization). The chemical treatments carried out by Greco Chemical are: neutralization, reduction, oxidation-reduction, oxidation decomposition, substitution, modification or decomposition of functional groups. In addition, the company provides treatment to waste to 


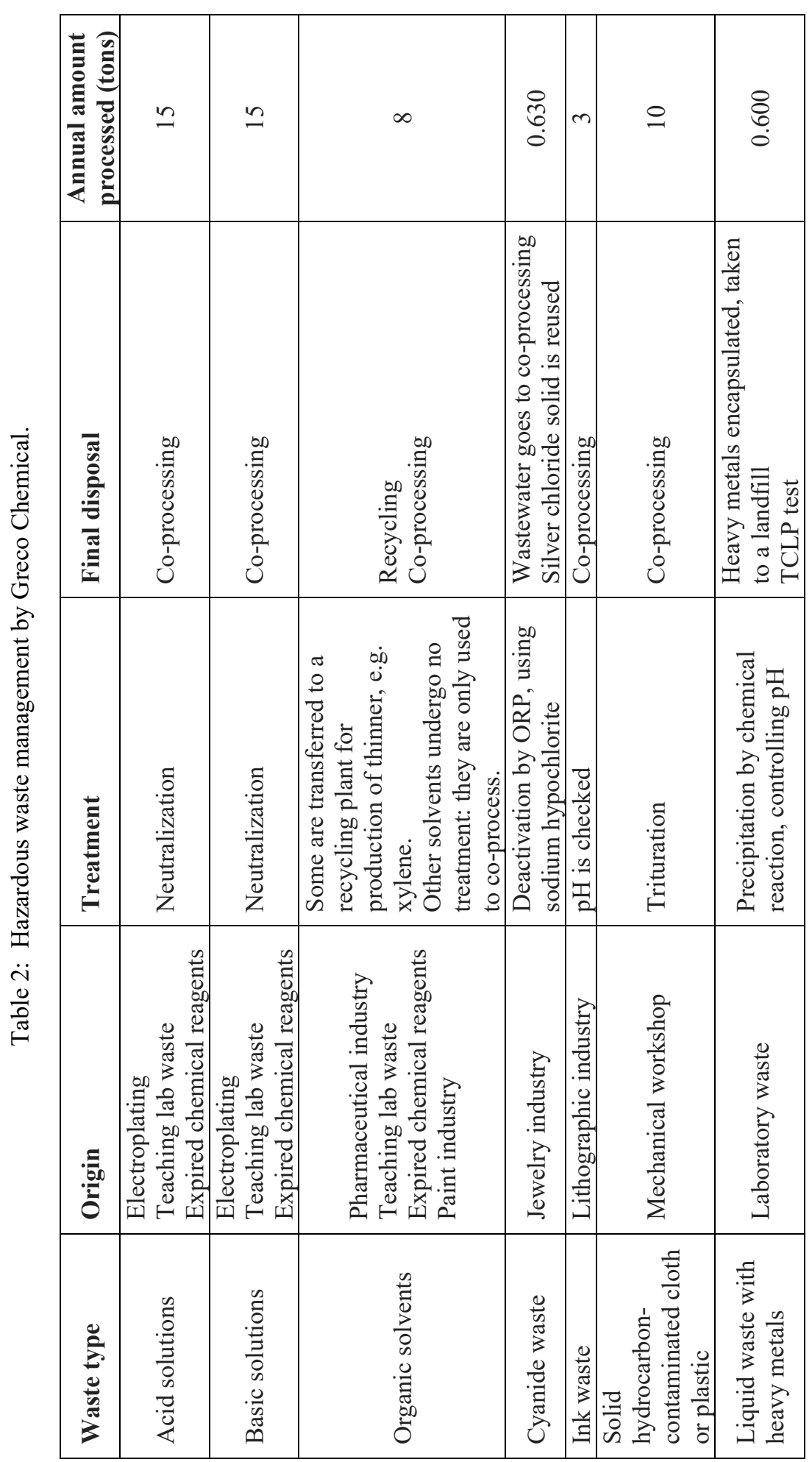


be managed through co-processing in a cement kiln. In the case of waste that cannot be recovered, it is disposed of in a sanitary landfill.

At Greco Chemical, prior to submitting any waste to treatment, it is analyzed, in order to determine the best way to manage it; and always seeking recovery, rather than co-processing, and trying to avoid final disposal in sanitary landfills. Fig. 2 shows the decision path followed in the company.

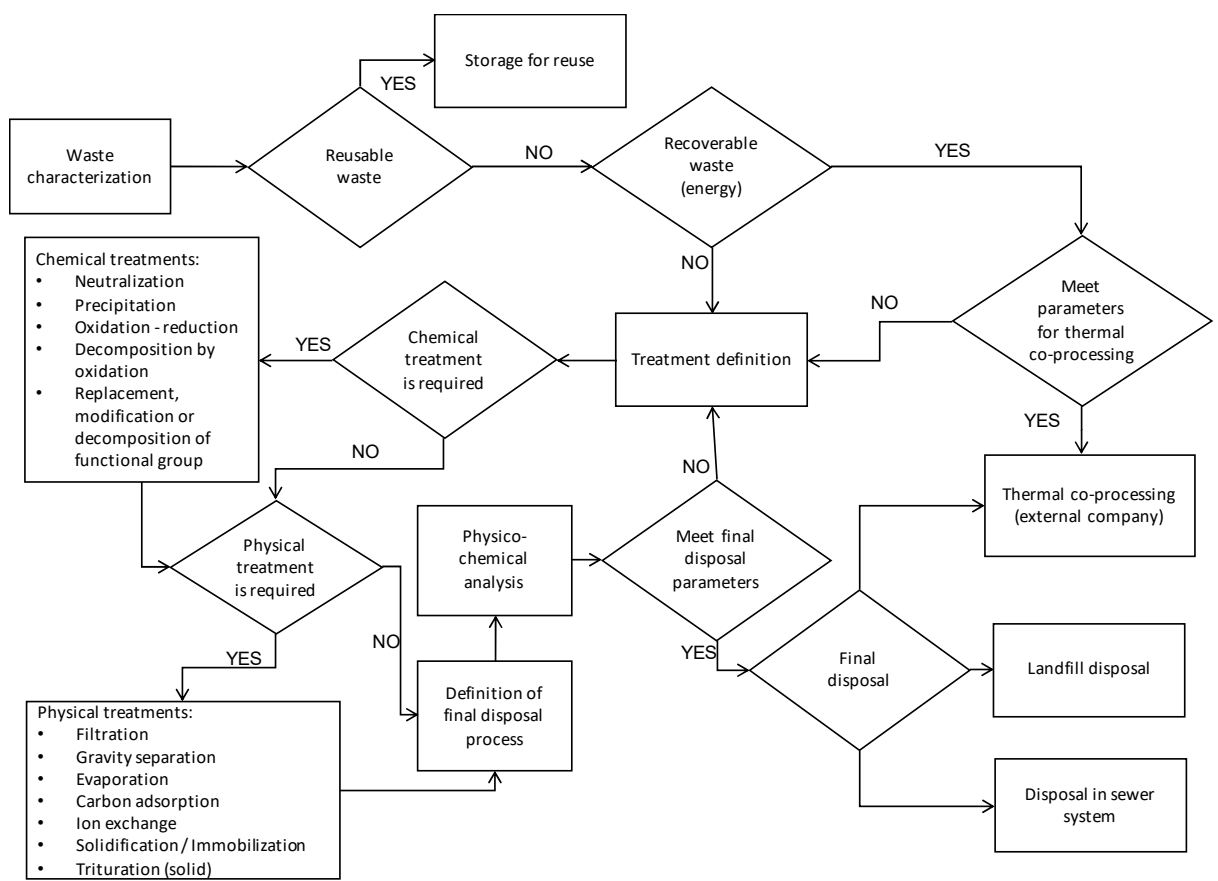

Figure 2: Decision diagram for waste management.

Among the chemical treatments carried out is the treatment for chromium residues (eqns (1) and (2)).

$$
\begin{aligned}
2 \mathrm{H}_{2} \mathrm{CrO}_{4} & +3 \mathrm{Na}_{2} \mathrm{HSO}_{3}+3 \mathrm{H}_{2} \mathrm{SO}_{4} \\
\mathrm{pH}=2.5-3.0, \mathrm{ORP}=250-300 \mathrm{mV}, & \mathrm{Cr}_{2}\left(\mathrm{SO}_{4}\right)_{3}+3 \mathrm{NaHSO}_{4}+5 \mathrm{H}_{2} \mathrm{O}, \\
\mathrm{Cr}_{2}\left(\mathrm{SO}_{4}\right)_{3}+3 \mathrm{Ca}(\mathrm{OH})_{2} & \longrightarrow 2 \mathrm{Cr}(\mathrm{OH})_{3}+3 \mathrm{CaSO}_{4},
\end{aligned}
$$

$\mathrm{pH}=8-9$.

Cyanide waste used in the jewelry industry is treated by oxidation with sodium hypochlorite (eqns (3) and (4)).

$$
\mathrm{NaCN}+\mathrm{NaOCl} \longrightarrow \mathrm{NaCNO}+\mathrm{NaCl}
$$

$\mathrm{pH}$ more than 10; ORP $=300-350 \mathrm{mV}$,

$$
2 \mathrm{NaCNO}+3 \mathrm{NaOCl} \longrightarrow 2 \mathrm{CO}_{2}+\mathrm{N}_{2}+2 \mathrm{NaOH}+3 \mathrm{NaCl},
$$

$\mathrm{pH}=7.5-8.0$; ORP more than $650 \mathrm{mV}$. 
Another example is the destruction of isocyanates by reaction with alcohol in an alkaline medium, to produce urethane (eqns (5) and (6)) [12], which is subsequently co-processed by the cement industry

$$
\begin{gathered}
\mathrm{ROH}+\mathrm{NH}_{3} . \longrightarrow \mathrm{RO}^{-}+\mathrm{NH}_{4}^{+}, \\
\mathrm{R}^{1}-\mathrm{N}=\mathrm{C}=\mathrm{O}+{ }^{-} \mathrm{OR} . \longrightarrow \mathrm{R} 1-\mathrm{NH}-\mathrm{COOR}+\mathrm{NH}_{3} .
\end{gathered}
$$

3.3 Final remarks: Importance of the synergy between the university and small hazardous waste managers

In Costa Rica, scientific research is mainly carried out in public universities; at the same time, synergy with private companies permits optimal results for technological and industrial development. In the particular case of Greco Chemical and the academic ITCR, a synergy occurred due to the educational center's need to responsibly manage the waste from its laboratories, while Greco Chemical lacked the knowledge and equipment of the specialized research laboratories; therefore, the ITCR provided the support required by Greco Chemical. As a result, it was possible to develop treatment systems and appropriate logistics for treatment and disposal of hazardous waste that enabled the environmental performance within the country to be enhanced.

\section{ACKNOWLEDGEMENTS}

The authors thank both Greco Chemical, for the information provided about the quantity of materials processed and its treatment system; and the Scholarship Committee of the ITCR, for registration fee payment.

\section{REFERENCES}

[1] Strategic Approach to International Chemicals Management (SAICM), Informe de la Conferencia Internacional sobre Gestión de los Productos Químicos relativo a la labor realizada en su tercer período de sesiones [Report from the SAICM International Conference, presented at the third period of sessions], Nairobi, 2012. www.who.int/ipcs/capacity_building/chemicals_management/saicm_iccm3_ sp.pdf?ua=1. Accessed on: 12 Mar. 2020.

[2] Asamblea Legislativa de Costa Rica [Costa Rica Legislative Assembly], Reglamento general para la clasificación y manejo de residuos peligrosos (41527-S-MINAE) [General rules for classification and handling of dangerous residues (41527-SMINAE)], Costa Rica, 2019. www.pgrweb.go.cr/scij/Busqueda/Normativa/Normas/ nrm_texto_completo.aspx?param1=NRTC\&nValor $1=1 \&$ nValor $2=88120 \& n$ Valor $3=$ 114959\&strTipM=TC. Accessed on: 2 Mar. 2020.

[3] Basel Convention, On the control of transboundary movements of hazardous wastes and their disposal. Basel Convention, Basel, Switzerland, 1989. www.basel.int/Portals/4/Basel\%20Convention/docs/text/BaselConventionText-e.pdf. Accessed on: 12 Mar. 2020.

[4] Asamblea Legislativa de Costa Rica [Costa Rica Legislative Assembly], Ley para la gestión integral de residuos (8839) [8839 Law about complete management of residues], Costa Rica, 2010. www.pgrweb.go.cr/scij/Busqueda/Normativa/Normas/ nrm_texto_completo.aspx?nValor1=1\&nValor2=68300. Accessed on: 2 Mar. 2020. 
[5] Asamblea Legislativa Costa Rica [Costa Rica Legislative Assembly], Reglamento sobre las características y listado de los desechos peligrosos industriales (27000MINAE) [27000-MINAE Rule about the characteristics and listing of dangerous industrial wastes], Costa Rica, 1998. www.pgrweb.go.cr/scij/Busqueda/Normativa/ Normas/nrm texto_completo.aspx?param1 $=$ NRTC\&nValor1 $=1 \&$ nValor $2=44467 \&$ n Valor3=95389\&strTipM=TC. Accessed on: 2 Mar. 2020.

[6] Asamblea Legislativa Costa Rica [Costa Rica Legislative Assembly], Reglamento para el Manejo de los Desechos Peligrosos Industriales (27001-S-MINAE) [27001-SMINAE Rule about the handling of dangerous industrial wastes], Costa Rica, 1998. www.pgrweb.go.cr/scij/Busqueda/Normativa/Normas/nrm_texto_completo.aspx?par am1 $=$ NRTC \&nValor1 $=1 \& n$ Valor2=54836\&nValor3=114966\&strTipM=TC .

Accessed on: 2 Mar. 2020.

[7] Asamblea Legislativa Costa Rica [Costa Rica Legislative Assembly], Reglamento sobre el procedimiento para llevar a cabo la prueba de extracción para determinar constituyentes que hacen un residuo peligroso por su toxisidad al ambiente (27002MINAE) [27002-MINAE Rule about the procedures for testing the extraction to determine the components that make a dangerous waste due to its environmental toxicity], Costa Rica, 1998. www.pgrweb.go.cr/scij/Busqueda/Normativa/Normas/ nrm_texto_completo.aspx?param $1=$ NRTC\&nValor $1=1 \&$ nValor $2=54838 \& n$ Valor $3=$ 60088\&strTipM=TC. Accessed on: 2 Mar. 2020.

[8] United States Environmental Protection Agency (US EPA), Test Methods for Evaluating Solid Waste, Physical/Chemical Methods, SW-846, Method 1311, US Government Printing Office: Washington, DC, 1992.

[9] Asamblea Legislativa Costa Rica [Costa Rica Legislative Assembly], Reglamento para el transporte terrestre de productos peligrosos (24715-MOPT-MEIC-S) [24715MOPT-MEIC-S Rule for the terrestrial transportation of dangerous products], Costa Rica, 1995. www.pgrweb.go.cr/scij/Busqueda/Normativa/Normas/nrm_texto completo.aspx?param $1=$ NRTC \&nValor $1=1 \&$ nValor $2=40953 \&$ nValor $3=80233 \&$ strT ipM=TC. Accessed on: 2 Mar. 2020.

[10] Asamblea Legislativa Costa Rica [Costa Rica Legislative Assembly], Reglamento de Centros de Recuperación de Residuos Valorizables (41052-S) [41052-S Rules for the centers for recuperation of valuable residues], Costa Rica, 2018. www.pgrweb.go.cr/ scij/Busqueda/Normativa/Normas/nrm_texto_completo.aspx?param1=NRTC\&nValo r1=1\&nValor2=86628\&nValor3=112489\&strTipM=TC. Accessed on: 2 Mar. 2020.

[11] Contraloría Ambiental [Environmental Comptroller], Informe de la gestion de residuos peligrosos año 2019, segun el SIGREP [SIGREP report on management of hazardous residues], Costa Rica, 2019. www.contraloriaambiental.go.cr/pag/inicio.php. Accessed on 11 Mar. 2020.

[12] Das Bakul, T.V., Reddy, R., Balaji, M.T.K. \& Veera Reddy, T., Development of ecofriendly neutralizing agents for toluene di-isocyanate. Research Journal of Chemical Sciences, 3(5), pp. 7-11, 2013. 